\title{
Paradigma Sintesis Tafsir Teks Al-Qur'an Menimbang Hermeneutika Pemaknaan Teks Jorge J.E Gracia Sebagai Teori Penafsiran Tekstual al-Qur'an
}

\author{
Syamsul Wathani ${ }^{1}$
}

\begin{abstract}
This article discusses Jorge J.E Gracia's understanding the text used as a theory of textual interpretation of the Qur'an. Its dicussion focuses on three points: (i) narration of the textuality of the Qur'an as the object of interpretation, (ii) Textual hermeneutics of Jorge J.E Gracia, and (iii) paradigm of textual interpretation of the Qur'an. It analizes the interpretative structure of the text by using content analysis over the discussed text. It finds that (1) al-Nasss is seen as the main consciousness as the Qur'an is read/touched (al-Maktüb), in which it has hurf, al-qur'ān, al-kitāb, āyāt, kalimāt dan ar-risālah. (2) Gracia's hermeneutics is used to discover the textual misunderstanding, using the development of textual interpretation, in identifying the historicity of the discussed text with its audiences. (3) this method emphasizes adequate understanding the text of the Qur'an, its audiences, and its contexts. In this scheme of analysis, the Qur'an is seen as not only as form, but also as a complex entity which covers construction, combination, and correlation.
\end{abstract}

\begin{abstract}
Abstrak
Artikel ini membahas konsep hermeneutika pemaknaan teks Jorge J.E Gracia sebagai teori penafsiran tekstual al-Qur'an, dengan tiga poin pokok bahasan: (i) narasi tekstualitas al-Qur' an sebagai obyek penafsiran (ii) hermeneutika teks Jorge J.E Gracia dan (iii) paradigma tafsir tekstual terhadap al-Qur'an. Pola kajian artikel ini diarahkan pada analisis interpretatifstrukturasi, dengan melakukan analisis isi (content analysis) pada karya utama tokoh. Artikel ini menemukan bahwa: (1) Konsep teks al-Qur'an atau al-Naș adalah kesadaran utama, sebab al-Qur'an adalah sesuatu terbaca/tersentuh (al-Maktūb), ia memiliki entitas hurf, al-Qur'ān, al-kitāab, āyāt, kalimāt dan alrisālah. (2) Nalar hermeneutis pemaknaan teks ala Gracia
\end{abstract}

${ }^{1}$ Dosen Sekolah Tinggi Agama Islam (STAI) Darul Kamal Kembang Kerang Lombok Timur. E-mail: Wathoni89@gmail.com. 
mengurai kesalahpahaman (misunderstanding) teks, dengan metode the development of textual interpretation, untuk menjembatani kesejarahan teks dengan keadaan audiens. (3) Paradigma tafsir tekstual dengan konsep "al-naș ș" bekerja dengan menekankan pada adanya pemahaman yang baik atas teks, audiens, konteks, karena teks al-Qur'an itu tidak sebatas tertulis dalam sebuah bentuk (form), ia begitu kompleks, ia sebuah konstruksi (construction), kombinasi (combination) dan korelasi (correlation).

Keywords: al-NașS, Hermenutika Pemaknaan Teks, Paradigma Tafsir Tekstual,".

\section{Pendahuluan}

Persoalan hermeneutika al-Qur'an bersifat sui genesis. Pada satu sisi ia berkaitan dengan teks dan konteks sosio-historis seorang penafsir, pada sisi lain menjadi semakin kompleks ketika hermeneutika sebagai sebuah metode, digunakan untuk melakukan pembaharuan pemikiran umat Islam terhadap teks agama. ${ }^{2}$ Hermeneutika sebagai sistem interpretasi masih menjadi polemik di kalangan umat Islam. Umat Islam pun terpecah dalam dua poros pemikiran, antara yang membela dan yang menggugat hermeneutika.

Kelompok yang membela dan menerima umumnya bersikap apresiatif disertai dengan sikap kritis, dengan melihat hermeneutika sebagai proses dialektika intelektual yang kreatif dalam memehami teks agama, atau divine text dalam bahasa Muhammad Syahrur. ${ }^{3}$ Sedangkan, kelompok yang menggugat dan menolak biasanya bersikap reaksioner dan apatis. Bahkan terkadang menggunakan cara-cara yang cenderung teologis-dogmatik, sehingga melahirkan tuduhan "pengkafiran" dan "pemurtadan" terhadap pemikir hermeneutis tersebut, sebagaimana yang dirasakan oleh Aḥmad Khalafullāh dan Nașr Hamid Abū Zayd. ${ }^{4}$

Dua poros ini bertikai pada dua poin mendasar : (1) elemen dasar hermeneutika sebagai disiplin ilmu memahami teks agama (al-Qur'an) dan (2) pada ketidaksesuaian beberapa elemen hermeneutika dengan 'ulüm al-tafsir sebagai perangkat resmi pemahaman al-Qur'an. Dua poin ini merupakan sisi

\footnotetext{
${ }^{2}$ Nașr Hamid Abū Zayd, Al-Quran, Hermeneutik dan Kekuasaan : Kontroversi dan Penggugat Hermeneutika al-Qur'an, Terj. Dede Iswadi ( Bandung: RQiS, 2003 ), 7.

${ }^{3}$ Muhammad Syahrūr, Muḥammad Syahrūr, "The Divine Text and Pluralism in Moslem Societies", terj. Muhammad Zaki Hussein dalam Sahiron Syamsuddin (dkk.), Hermeneutika al-Qur'an Madzhab Yogya(Yogyakarta: Islamika, 2003), 257.

${ }^{4}$ Abu Zayd, Al-Quran, Hermeneutik dan Kekuasaan, 7-8.
} 
Paradigma Sintesis Tafsir Teks Al-Qur'an Menimbang Hermeneutika Pemaknaan Teks Jorge J.E Gracia Sebagai Teori Penafsiran Tekstual al-Qur'an

persoalan ontologis hermeneutika dan kaitannya sebagai episteme dalam memahami al-Qur'an yang sampai sekarang masih diperdebatkan.

Artikel ini akan menjawab titik polemis dua poros diatas, dengan menjadikan hermeneutika pemaknaan teks Jorge J.E Gracia sebagai titik tolak. Di antara sekian banyak penggagas hermeneutika, hermeneutika model Jorge J.E Gracia memiliki tempat tersendiri. Bahkan, bisa dibilang ia berada dalam aliran hermeneutika yang moderat. Sebagaimana pemetaan Sahiron Syamsuddin, yang menempatkan posisi Jorge J.E Gracia dalam aliran obyektivis-cum-subyektivis, atau aliran tengah-tengah antara dua aliran sebelumnya-obyektifis dan subyektifis. ${ }^{5}$ Kata moderat dalam hermeneutika ini, dikarenakan hermeneutika yang dianut oleh Gracia ini menekankan pada keseimbangan antara pencarian makna asal teks dan peran pembaca dalam penafsiran. Sehingga secara 'kasat mata', model hermeneutika Gracia ini dimungkinkan bisa diaplikasikan dalam ranah pengembangan ilmu al-Qur'an dan tafsir.

Jorge J.E Gracia memiliki dua karya monumental mengenai kajian teks, bahasa dan pemahamannya, yakni: Text; Ontological Status, Identity, Author, Audiens dan A Theory Of Textuality: The Logic And Epistemology. Karya pertama memuat pemikiran Gracia mengenai teks beserta kempleksitasnya, sedang karya kedua memuat pemikirannya mengenai teori pemahaman ( a theory of meaning).

Artikel ini fokus pada karya Gracia yang kedua. Dengan metode analisis interpretatif-strukturasi, artikel ini tidak akan menganalisis isi (content analysis) dengan alur eksploratif semua isi dari karya Gracia tersebut, melainkan memetakan beberapa poin pemikiran Gracia mengenai teori pemahaman serta mensistematisasikan gagasan Gracia mengenai teori pemahaman tersebut dalam sebuah rumusan teori untuk digunakan sebagai teori interpretasi al-Qur'an.

Artikel ini akan beroperasi pada tiga pembahasan: (1) posisi penafsiran al-Qur'an sebagai teks, (2) interpretasi teks atau teori pemaknaan teks menurut Gracia serta kemungkinan teoritis pemahaman teks ala Gracia sebagai teori interpretasi tekstual al-Qur'an. Core study artikel ini menekankan pada kajian teoritis, bukan praktis secara langsung pada penafsiran al-Qur'an. Dalam arti, melihat kemungkinan teori pemaknaan teks Gracia dengan alur teori tafsir yang berlaku di dunia Islam.

5 Sahiron Syamsuddin, Hermeneutika dan Pengembangan Ulumul Qur'an, (Yogyakarta: Pesantren Nawesea Press, 2009), 26-27. 
Dengan fokus pada beberapa pembahasan di atas, artikel ini diharapkan dapat memberikan pemahaman mengenai pola dan alur interpretasi al-Qur'an sebagai teks. Menarasikan teori intepretasi tekstual al-Qur'an dalam tradisi Islam, menganalisis dan merumuskan dengan baik teori pemaknaan teks menurut Jorge J.E Gracia, serta mengkomparasikan dan melihat kemungkinankemungkinan teori pemaknaan teks Jorge J.E Gracia untuk digunakan dalam memahami al-Qur'an. Dengan ini, tanpa memandang negatif semua model hermenutika, bukan tidak mungkin tawaran hermeneutika Gracia ini bisa dijadikan "pembacaan alternatif" yang dapat menghiasi interpretasi al-Qur' an di masa Kontemporer.

\section{Sejarah Intelektual Jorge J.E Gracia}

Gracia dilahirkan di Kuba pada tahun 1942. Ia adalah seorang professor dalam bidang filsafat di Departement of Philosophy, University at Buffalo, New York. Sejarah intelektualitas filsafatnya dimulai dari undergraduate program dalam bidang filsafat di Wheaton Collage (1965), kemudian melanjutkan ke graduate program dalam bidang yang sama di University of Chicago (1966). Ia meraih gelar doctor dalam bidang yang sama di University of Toronto pada tahun $1971 .^{6}$

Gracia adalah salah satu hermenian dengan core study terkait terintegral, yakni: metafisika/ontology, historiografi filosofis, filsafat bahasa/hermeneutika dan filsafat skolastik. Dengan core study tersebut, ia kini menjadi professor di Universitas Buffalo sekaligus filosof yang terkenal di Amerika. Di samping menjadi pengajar filsafat, Gracia juga aktif di berbagai organisasi sosial yang concern terhadap isu etnisitas, identitas dan nasionalisme dan lain-lain. ${ }^{7}$

Ada dua karya Gracia yang memanifestasikan pemikirannya di bidang filsafat bahasa, Text; Ontological Status, Identity, Author, Audiens dan A Theory Of Textuality: The Logic And Epistemology. Karya pertama Gracia memunculkan beberapa ide dan pemetaan mengenai kepengarangan sebuah teks. Dalam studi hadis, teori mengenai "kepengarangan teks" yang dipetakan oleh Gracia digunakan dalam mengaji hadis, terutama masalah tahrif (pengurangan), yakni untuk mengetahui dari mana sebuah redaksi hadits mulai berubah dan diriwayatkan dengan redaksi berbeda sampai ke sanad terakhir

${ }^{6}$ Sahiron Syamsuddin, Hermeneutika dan Pengembangn 'Ulumul Qur'an, hlm. 52.

${ }^{7}$ Biografi Gracia diambil dari website University at Buffalo, New York, yaitu www.acsu.buffalo.edu/gracia/cv.html, diakses tanggal 27 Maret 2014. 
Paradigma Sintesis Tafsir Teks Al-Qur'an Menimbang Hermeneutika Pemaknaan Teks Jorge J.E Gracia Sebagai Teori Penafsiran Tekstual al-Qur'an

(mukharrij). Sedangkan karya yang kedua merupakan lanjutan dari karya yang pertama. Karya ini memuat ide-ide Gracia terkait dengan teori pemaknaan teks.

\section{Hermeneutika Pemaknaan Teks Jorge J.E Gracia}

\section{Al-Qura'an: Persepsi Tekstualitas}

Persepsi mengenai al-Qur'an terbangun dari horizon keilmuan serta membangun hasil tafsir/teori tafsir yang dibangun oleh mufassir. Cara pandang terhadap al-Qur'an memiliki poin penting dalam melahirkan corak tafsir. Sebagian tokoh memandang al-Qur'an sebagai nilai yang berjalan, sebagai teks yang baku, sebagai qanūn yang qat'i, sebagai dokumen sosial dan lain sebagainya. Dalam pendahuluannya terhadap Mafhūm al-Nașṣ, Naṣr Hāamid Abū Zayd menyebutkan bahwa peradaban Arab adalah peradaban teks, dan al-Qur'an merupakan teks sentral dalam sejarah peradaban Arab. ${ }^{8}$ Dengan demikian, dapat dipahami mengapa al-Qur'an menjadi salah satu teks yang paling berpengaruh di tanah Arab dan bahkan di dunia.

Posisi Abū Zaid demikian bisa difahami, mengingat penyampaian alQur'an yang tersebar ke penjuru penduduk Islam adalah teks yang tampak terbaca/tersentuh (al-kitāb al-maktūb), sehingga sisi tekstualitasnya sangat penting diakui. Dalam bentuk apapun, tekstualitas al-Qur'an adalah benang makna yang tampak, di dalamnya ada nilai, ajaran dan pesan ilahi yang dapat digali. Walaupun terkadang tafsir terhadapnya memperlihatkan wajah justifikasi mazhabi, lahan kontestasi pemikiran dan politik, sisi tekstualitasnya tetaplah harus menjadi obyek utama dalam menafsirkan. ${ }^{9}$

Persepsi mengenai al-Qur'an melahirkan teori tafsir tersendiri yang kemudian menjadi ke-khasan bagi seorang mufassir dalan mencari makna. Pada akhirnya mereka pun akan memiliki konsepsi tersendiri setelah melakukan penafsiran. Dalam bentuk teks, al-Qur'an pertama dikenal dengan pencarian makna ayat melalui ayat-ayat lainnya. Adakalanya sebuah ayat memiliki makna yang ambigu atau tidak jelas, ia butuh pendukung yang bisa ditemui di ayatayat lainnya. Hal demikian kemudian tampak menjadi penguat akan urgensi untuk selalu menempatkan tekstualitas al-Qur'an sebagai kesadaran awal bahwa al-Qur'an adalah teks ytang tersentuh.

\footnotetext{
${ }^{8}$ Nașr Hāamid Abū Zayd, Mafhūm al-Nașs: Dirāsàt fí 'Ulūm al-Qur'ān (Beirūt alMarkaz al-Ṣaqāî̀ al-'Arabi, 2000), 6-7.

${ }^{9}$ Panutan ini kemudian melahirkan kaidah penafsiran al-Qur'an yang banyak menyentuh sisi teksnya. Lihat : Khālid ibn 'Uthmān al-Sabt, Qawā'id al-Tafsir: Jam'an wa Dirāsatan (Kairo: Dār Ibn 'Affān, $1421 \mathrm{H})$. Khalid Abd al-Rahman al-'Akk, Ușul alTafsìr wa Qawā'iduhu (Beirūt: Dār al-Nafā' is, 1986).
} 
Sebelum Nașr Hāamid, penyebutan al-Qur'an sebagai teks sudah dikonsepkan oleh Amin al-Khulli, yang memperlakukan teks sakral (al-Qur'an) sebagai kitab sastra Arab terbesar (kitāb al-arabiyyah al-akbar), yaitu dengan dua kajian : kajian di sekitar al-Qur'an (dirāsah mā hawl al-Qur'ān) dan kajian terhadap al-Qur'an itu sendiri (dirāsah fí al-Qur'ān nafsih). ${ }^{10}$ Selain al-Khuli , terdapat Muhammad Khalafullah (murid dari al-Khuli ) yang juga memosisikan Al-Qur'an sebagai karya sastra yang profan. ${ }^{11}$

Setelah kedua tokoh ini, Nașr Hāmid mengafirmasikan tekstualitas AlQur'an secara lebih tertata. Tekstualitas al-Qur'an berkaitan dengan tiga hal, salah satunya bahwa kata wahy dalam al-Qur'an secara semantik setara dengan perkataan Allah (kalam Allah, verbum dei) dan Al-Qur'an adalah sebuah pesan (risalah). Sebagai perkataan dan pesan, Al-Qur'an meniscayakan dirinya untuk dikaji sebagai sebuah "teks". 12 Al-Qur'an adalah teks karena ia terkait dengan ruang dan waktu dalam pengertian historis dan sosiologis, di mana ia tidak berada di luar kategori bahasa. Dan ketika Al-Qur'an berada dalam kerangka bahasa dan memiliki kaitan dengan manusia (historis), maka akan selalu ada perangkat epistemologis dan prosedural untuk mengkajinya. ${ }^{13}$

Tekstalitas al-Qur'an sebenarnya dapat difahami dari komposisi yang dimilikinya, ia adalah : hurf, al-qur'ān, al-kitāb àyāt, kalimāt dan ar-risālah. Oleh sebab itu, Nașr Hāmid memandang al-Qur'an sebagai objek kajian, layaknya kajian terhadap teks-teks umum lainnya. Naṣr Hāmid menegaskan bahwa teks yang dalam bahasa Arabnya naș ini pernah dikonsepsikan berbeda oleh aliran kalam pada abad awal Islam. ${ }^{14}$ Keluar dari perdebatan itu, Nașr Hāmid menegaskan bahwa posisi sebagai teks yang memiliki mekanisme teks, sehingga memahami al-Qur'an tidak selalu didekati dengan cara teologi-mistik, tetapi juga perlu diperhatikan realitas yang menunt ut agama juga harus didekati

${ }^{10}$ Mohammad Nur Kholis, "Pengantar" ,dalam buku J.J.G. Jansen, Diskursus Tafsir Al-Qur'an Moderen (Yogyakarta: Tiara Wacana, 1997), xv.

${ }^{11}$ Muhammad Aunul Abied Shah, "Amin Al-Khuli dan Kodifikasi Metode Tafsir: Sebuah Biografi Intelektual” dalam Aunul Abied Syah (ed.), Islam Garda Depan: Mosaik Pemikiran Islam Timur Tengah (bandung: Mizan, 2001), 133.

${ }^{12}$ Moch. Nur Ichwan, “Al-Qur' an sebagai Teks: Teori Teks dalam Hermeneutika Qur'an Nasr Hāmid Abū Zayd" dalam Abdul Mustaqim dan Sahiron Syamsudin (ed.), Studi al-Qur'an Kontemporer; Wacana Baru Berbagai Metodologi Tafsir (Yogyakarta: Tiara Wacana, 2002), 154.

${ }^{13}$ Nașr Hạamid Abū Zayd, Teks Otoritas Kebenaran (Yogyakarta: LkiS, 2003), hlm. 113.

${ }^{14}$ Konsepsi perdebatan klasik aliran kalam Islam mengenai al-Qur'an lihat: Nașr Hāmid Abū Zayd, al-Nașs, al-Sulțah, al-Haqīqah: al-Fikr al-Dīn̄ bain Iradat al-Ma'rifat wa Iradat al-Haiminat (Beirūt: al-Markaz al-Thaqafi al-'Arabi, 1995), hlm. 68-69. 
secara rasional-ilmiah. Posisi ini menentukan sikap banyak pemikir Islam, bahwa al-Qur'an itu membutuhkan ilmu di atas keyakinan semata.

Persepsi al-Qur'an sebagai teks memiliki banyak konsepsi pula, ia sebagai teks biasa (Qur'an as text), sebagai literatur keagamaan (Qur'an as literature), sebagi teks suci (Qur'an as sacret text) sehingga melahirkan alQur'an dan teori tekstualitas mengenainya. Mengakui secara natural al-Qur'an sebagai kitab/buku/scripture adalah kesadaran awal baru kemudian membahas prinsip kebahasaan/ketekstualan/semantik yang lebih bersifat metodis dalam memahaminya sebagai teks. Namun teori teks semata nampak tidak adil bagi pemikir lain. Hal ini karena al-Qur'an sebagai divine writing (kitab wahyu) bersifat interpenetrated dan cair. Oleh sebab itu, pendekatan yang menekankan bahwa ia merupakan buku atau tulisan menjadi tidak adil jika dijadikan satusatunya pendekatan, perlu dilengkapi dengan mempertimbangkan kerumitan pemaknaan dan penjelasan al-Quran terhadap kondisinya sebagai kitab wahyu tersebut.

Dari sini dapat disimpulkan bahwa atas penyapaan Tuhan kepada manusia lewat Al-Qur'an dalam bahasa yang manusiawi (historis) tersebutlah yang kemudian menjadi lahan untuk didekati secara lingustik, ${ }^{15}$ apalagi tampilan dari Al-Qur'an itu sendiri (dalam wujud teks dan dalam kemasan bahasa manusiawi) berpotensi dan meniscayakan ia diberlakukan sebagai tekssebagaimana teks-teks profan pada umumnya. Sehingga menjadi wajar kalau kemudian para pemikir Islam mulai mendekati al-Qur'an dari sudut linguistik (kebahasaan) atau mengkajinya sebagai sebuah teks.

\section{Hermeneutika Teks Gracia}

Kata "hermeneutika" diambil dari bahasa Yunani, "hermeneuein" yang berarti "menjelaskan" (to explain). ${ }^{16}$ Dalam operasionalnya, hermeneutika bisa difahami sebagai proses mengubah sesuatu dari situasi dan makna yang tidak dapat diketahui menjadi makna yang dapat dimengerti. ${ }^{17}$ Jika dikaitkan dengan teks keagamaan (divine text), maka hermenutika dalam bahasa Komarudin Hidayat, membumikan "bahasa langit" kepada manusia yang menggunakan

${ }^{15}$ Menurut Abū Zayd, adanya komponen kata-kata bahasa dalam sebuah teks AlQur'an meniscayakan penerapan metode linguistik terhadapnya. Hilman Latief, Nasr Hāmid Abū Zayd, h. 84. Toshihiko Izutsu, Relasi Tuhan dan Manusia: Analisis Semantik terhadap Weltanschauung Al-Qur'an, terj. Agus Fachri Husain dkk. (Yogyakarta: Tiara Wacana, 1997), 166.

16 Fahruddin Faiz, Hermeneutika Al-Qur'an; Tema-Tema Kontroversial, (Yogyakarta: Elsaq, 2005), 4.

${ }^{17}$ Khamdan (Dkk.), Studi Al-Qur'an: Teori dan Metodologi, (Yogyakarta: Idea Press, 2011), 163. 
"bahasa bumi". ${ }^{18}$ Definisi hermeneutika ini -sebagai ilmu interpretasi- ${ }^{19}$ sangat mirip dengan definisi al-Zarqānì dalam definisinya mengenai tarjamah alQur'an, yakni : memindahkan/mengubah kalam dari satu bahasa ke bahasa lain (naqlu al-kalām min lughah ilā lughah ukhrā). ${ }^{20}$

Problem hermeneutik selalu mempersoalkan jarak ruang dan waktu antara pengarang dengan pembaca. Dikarenakan dalam rentangan jarak tersebut besar kemungkinan pembaca tidak bisa memahami secara jelas kata-kata, istilah-istilah dan kalimat- kalimat yang dibuat pengarang. Kekeliruan adalah suatu hal yang selalu membayangi dalam setiap proses penafsiran dan karena persoalan jarak itu pula, seseorang bisa memanipulasi makna teks sesuau dengan keinginan subjektifnya.

Hal ini sering terjadi pada proses interpretasi teks al- Qur'an. Terkadang, seorang penafsir dengan sengaja atau tidak telah 'memperkosa' makna teks alQur' an demi kepentingan diri sendiri atau kelompoknya. Sehingga interpretasi menjadi bersifat subjektif-ideologis-tendensius. ${ }^{21}$ Menghindari hal ini, Gracia menawarkan konsep dan penataan kembali paradigma mengenai teks dan upaya untuk memahaminya. Tentu, Gracia bukanlah orang yang pertama menawarkan ide ini. Jauh sebelumnya, beberapa ulama' klasik seperti Ibn Qutaybah teori pemaknaan, yakni: teori lafži, yang mencakup leksikan dan struktural dan teori maknawi yaitu teori makna. Teori ini lahir sebagai respon dari ragam gaya tutural-Qur'an itu sendiri. ${ }^{22}$

Namun Gracia muncul dengan konsep baru dengan dua karya monumentalnya. Dengan latar sejarah intelektual yang berbeda, bisa dibilang ide Gracia khas dibandingkan dengan kebanyakan pemikir hermeneutika lain. Jika karya Syahrur disebut khas dengan analisis dari latar keilmuan sains yang digunakan dalam memahami dan merumusakn teori interpretasi al-Qur'an pembacaan modern (qira'ah al-mu'ashirah), ${ }^{23}$ maka, Gracia hadir dengan

${ }^{18}$ Komaruddin Hidayat, Memahmi Bahasa Agama: Sebuah Kajian Hermeneutik (Jakarta: Paramadina, 1998), 13.

${ }^{19}$ Khamdan (Dkk.), Studi Al-Qur'an: Teori dan Metodologi, 166.

${ }^{20}$ Muhạmmad Abdul Az̄ìm al-Zarqānī, Manāhil al-Irfān fì Uhūm al-Qur'ān, (Beirūt: Dār al-Kutub al-Ilmīyah, 2010), 328-329.

${ }^{21}$ Nașr Hāàmid Abū Zayd, Naqd Khitāab al-Dīni (Cairo: Sina li al-Nașr, 1992), 142-144. Syahiron Syamsuddin, Hermeneutika dan Pengembangan Ulumul Qur'an,. 5556.

${ }^{22}$ M. Nur Kholis setiawan, Al-Qur'an Kitab Sastra Terbesar, (Yogyakarta: Elsaq Press, 2006), 193-195.

${ }^{23}$ Muhammad Syahrūur, al-Kitāb wa al-Qur'ān: Qirāăah Mu'āshirah (Damaskus, al-Ahāli,1990), 30-32. 
penguasaan historiografi dan filsafat. Penguasaan ini yang menjadi basis argumentasi lahirnya dua karya tersebut yang saling melengkapi.

\section{Status Interpretasi}

Bagi Gracia, fungsi pokok dari teks adalah menyampaikan makna kepada audiens. Maka, produksi pemahaman bagi audiens merupakan hal yang urgent. Pemahaman audiens terhadapat teks beragam dan bervariasi antara satu audiens dengan audiens yang lain. Karena itu, tidak mengherankan jika dalam beberapa kasus, akan banyak ditemukan ketidakpahaman (misunderstanding), bukan pemahaman (understanding) itu sendiri. ${ }^{24}$

Interpretasi tidak dapat dilepaskan dari objek interpretasinya yaitu teks. Bagi Gracia, teks merupakan entitas sejarah yang terbentuk dalam situasi dan waktu tertentu yang melingkupi pengarangnya. Karena itu, seorang penafsir teks memiliki dua posisi dan tugas. Di satu sisi sebagai historian yang mencoba kembali ke makna sejarah, dan di sisi lain menjadi seorang philoshoper yang berusaha mencari dan menciptakan makna. ${ }^{25}$

Kenyataan yang perlu dibangun dalam jiwa penafsir teks menurut Gracia adalah kesadaran bahwa seseorang tidak bisa mengakses langsung kepada makna, ia hanya bisa mengakses kepada teks (entitas makna), yang menjadi wadah dari ide dan makna sang pengarang. ${ }^{26}$ Narasi interpretasi menurut Gracia di atas, merincikan pada elemen-elemen penting dalam interpretasi, yang meliputi: kesejarahan, kepengarangan, konteks pengarang, konteks audiens, kontek penafsir, dll. Kesadaran seorang penafsir menjadi penting, karena hal tersebut yang akan mempengaruhi langkah-langkah dalam menafsirkan. ${ }^{27}$

${ }^{24}$ Jorge J. E. Gracia, A Theory Of Textuality: The Logic And Epistemology (Albany: State University Of New York Press, 1995), 147-148.

${ }^{25}$ Karena Itu Sahiron Syamsudin memasukkan Gracia pada Aliran ketiga, aliran Obyektivis-cum-subyektivis atau aliran tengah-tengah antara dua aliran hermeneutika lainnya. Pemikiran yang masuk pada kategori ini adalah pemikiran Gadamer dan Gracia. Aliran ini memberikan keseimbangan antara pencarian makna asal teks dan peran pembaca dalam penafsiran. Karena itu penekanan faktor internal dan eksternal seorang pengarang dan pembaca menjadi penting dikaji dalam aliran ini. Baik Gadamer maupun Gracia, keduanya mengkritik nalar hermeneutik yang dibangun oleh Schleiermacher dan Dilthey dalam masalah teks. Menurut mereka, interpretasi tidak sama dengan mengambil suatu teks, lalu mencari arti teks sebagaimana dimaksud pengarang. Sebaliknya, arti suatu teks tetap terbuka sesuai dengan horison penafsir. Komarudin Hidayat, Memahami Bahasa Agama, 43. Syahiron Syamsuddin, Hermeneutika dan Pengembangan Ulumul Qur'an, 44-52.

\footnotetext{
${ }^{26}$ Jorge J.E. Gracia, $A$ Theory of Textuality, 147-148.

${ }^{27}$ Jorge J.E Gracia, $A$ Theory of Textuality, 101.
} 
Fenomena yang sering terjadi menurut Gracia, dalam memahami teks, seringkali audiens menggunakan cara yang berbeda dari cara yang digunakan oleh pengarang historis dalam memahami teks. Akibatnya, terjadilah semacam ketidakpahaman (misunderstanding). Padahal, dalam memahami teks, audiens tidak mempunyai akses langsung ke pemahaman sang pengarang historis. Dengan ini, maka bisa dipastikan mustahil jika pemahaman audiens terhadap teks itu mempunyai kesamaan dengan sang pengarang historis. Kesadaran ini akan membuat ruang klaim penafsiran menjadi hilang dengan sendirinya. Ide besar Gracia dalam menjawab problem ini adalah, merumuskan beberapa hal mengenai sifat pemahaman dan relasinya dengan makna, jumlah pemahaman dan keterikatan pemahaman dengan teks, serta keterkaitan pemahaman terhadap identitas tekstual. ${ }^{28}$

Gracia menawarkan metode "the development of textual interpretation" yang akan mencoba menjembatani antara keadaan kesejarahan teks dengan keadaan audience pada masa sekarang beserta implikasinya. Mengawali tawarannya ini, Gracia memberikan pandangan bahwa ada tiga faktor yang membentuk dan saling kerjasama dalam sebuah rangkaian interpretasi, antara lain: Pertama, teks yang akan ditafsirkan (interpretandum) yang meliputi kesejarahan teks. Kedua, penafsir (interpreter) adalah pelaku atau orang yang akan melakukan pencarian makna historis teks dan akan membentuknya ke makna baru beserta implikasianya dengan fungsi interpretasi. Ketiga, tambahan makna (interpretans) yang merupakan kreasi dari interpreter, yang pada akhirnya gabunagn dari interpretandum dan interpretans inilah yang dinamakan penafsiran. $^{29}$

\section{Pemahaman dan Makna}

Dalam kitab tafsir klasik dan ilmu tafsir, tafsir selalu didefinisikan dengan makna dasar menyingkap dan menjelaskan (al-kasyf wa al-bayān), ${ }^{30}$ yang kemudian secara praksis melahirkan tiga aktivitas menafsirkan al-Qur'an, yakni: memahami (al-fahm), menjelaskan (al-bayān), dan mengeluarkan makna (istikhrāj). Bisa dibilang ini adalah tiang penafsiran al-Qur'an. Dalam bentuk apapun penafsiran al-Qur'an, pilar ini menjadi fondasi kuat. Dalam pandangan Gracia pemahaman tidaklah sama dengan makna. Pemahaman merupakan aktifitas mental ketika seseorang sedang memahami sesuatu, di mana dalam

\footnotetext{
${ }^{28}$ Jorge J.E Gracia, A Theory of Textuality, 101.

${ }^{29}$ Jorge J. E. Gracia, $A$ Theory Of Textuality, 149-150.

${ }^{30}$ Muhammad Husein al-Zahabī, at-Tafsìir wa al-Mufassirūn (Cairo: Maktabah
} Wahbah, t.t.), 1-12. 
Paradigma Sintesis Tafsir Teks Al-Qur'an Menimbang Hermeneutika Pemaknaan Teks Jorge J.E Gracia Sebagai Teori Penafsiran Tekstual al-Qur'an

konteks teks adalah makna. Sedangkan makna teks tidak memerlukan aktifitas mental dan karenanya tidak bisa identik dengan pemahaman. Begitu juga meskipun pemahaman adalah sebuah aktifitas, akan tetapi didalamnya terdiri dari sekelompok aktifitas (a series group of acts) atau berbagai aktifitas dalam waktu bersamaan. Gracia mengatakan:

"Understand is not however, the some as meaning. Understanding is a kind of a mental act where by one grasps something, which in the case of texts is their meaning"

"Pemahaman tidaklah sama dengan makna, pemahaman merupakan aktivitas mental ketika seseorang sedang memahami sesuatu, di mana dalam konteks teks adalah makna". ${ }^{31}$

Dari ungkapan ini, dapat dipahami bahwa memahami merupakan sebuah aktivitas mental yang sedang berusaha dalam menggali dan mendapatkan makna dari sebuah teks. Memahami berarti memutar psikologi dan karakter personal dalam menafsirkan, sebelum hasil penafsiran tersebut di publish ke publik. Adapun al-bayān (dalam bahasa Gracia "explain”) adalah langkah selanjutnya setelah memahami (fahm). Seorang penafsir ketika setelah memahami makna teks, ia harus menjelaskan makna teks dalam bentuk tulisan ataukah suara (speaking form) dengan menggunakan sebuah metode dan memberikan tambahan makna (additional information) serta analisis. Tawaran Gracia mengenai bayan inilah yang disebut dengan teorinya mengenai historical function and meaning function of interpretation. ${ }^{32}$ Terma istikhrāj (take out) telah disempurnakan maknanya oleh Gracia dalam teorinya implicative function of interpretation. ${ }^{33}$

Bagi Gracia, menyatakan membedakan pemahaman dan makna itu sangatlah penting, karena pembedaan ini memperjelas bahwa dalam memahami teks tidak dapat direduksi dengan pemahaman sang pengarang ataupun suatu keterangan yang berkaitan dengan pengarang. Karena itu, untuk memahami sebuah teks bukanlah memahami sesuatu yang berhubungan dengan aktifitas yang dilakukan oleh pengarang teks ketika ia menghasilkan teks, ataupun memahami tentang sesuatu yang berkaitan dengan diri pengarang sendiri.

Aktifitas pemahaman ini terfokuskan pada makna teks dan bukan pada sang pengarang dan aktifitas sang pengarang dalam memahami teks. Karena dalam memahami teks, bisa jadi audiens memilih cara yang berbeda dengan sang pengarang di mana sang pengarang sendiri tidak mengantisipasinya.

\footnotetext{
${ }^{31}$ Jorge J. E. Gracia, A Theory Of Textuality, 103.

${ }^{32}$ Jorge J. E. Gracia, $A$ Theory Of Textuality, 155-157.

${ }^{33}$ Jorge J. E. Gracia, A Theory Of Textuality, 160-161.
} 
Pemahaman audiens sering kali berbeda dan bahkan berseberangan dengan pemahaman sang pengarang historis. Maka, bagi Gracia pemahaman adalah aktivitas orang per orang yang tidak bisa diseragamkan, olehnya, akan terdapat pemahaman yang beragam dan bervariasi dari setiap orang yang mencoba memahami sebuah teks. Persoalan terkait bervariasinya pemahaman terhadap suatu teks, bagi Gracia merupakan bukti yang paling nyata dari konsep teks sebagai aktifitas mental yang terjadi di dalam fikiran siapapun yang memahami teks.

Gracia mendetailkan penjelasan tersebut dengan konsep intensional dan ektensional dalam aktifitas memahami teks. Konsep ekstensional terkait pada aktifitas individu dalam memahami, sedangakan konsep intensional berkaitan pada makna yang dipahami melalui aktifitas tersebut. Oleh karena itu seseorang bisa mengatakan aktifitas pemahaman secara intensional sama karena apa yang dipahami melalui aktifitas tersebut adalah makna yang sama, tetapi secara ekstensional berbeda karena mereka secara individu berbeda aktifitas pemahaman.

Dalam hermeneutika pemaknaan teks, ada tiga elemen yang terlibat dalam membangun makna, masing-masing mempunyai dunianya sendiri. ${ }^{34}$ Pemahaman terhadap teks bagi Gracia bukan memahami teks itu sendiri, tetapi pemahaman terhadap makna yang terkandung di dalam teks. Teks tidak bisa disamakan dengan makna. Karena tiga elemen tersebut adalah entitas yang terpisah yang akan digerakkan semua dalam memahami teks, yakni : (a) teks yang harus dipahami atau pemaham terhadap makna yang dikandung teks, (b) audiens yang memahami teks dan (c) aktifitas dalam memahami makna yang terkandung dalam teks. ${ }^{35}$

\section{Elemen - elemen Interpretasi Teks}

Kompleksitas teks dalam definisi Gracia di atas membuat beberapa elemen mengenainya menjadi hal yang tak terpisahkan. Bagi Gracia, teks memiliki beberapa elemen-elemn interpretasi yang perlu difahami, antara lain:

(1) Pengarang. Merupakan orang yang membatasi makna teks, sebab ia adalah pembuat teks itu sendiri. Seorang pengaranglah yang menyusun dan menyeleksi tanda-tanda sehingga terbentuklah sebuah teks. Melalui media teks pengarang menyampaikan makna yang spesifik kepada audiens. Pengarang tidak hanya bertangungjawab pada pemberian makna entitas yang mendasari teks yang digunakan, tetapi juga pada makna itu sendiri serta ia bertanggungjawab

\footnotetext{
${ }^{34}$ Komarudin Hidayat, Memahami Bahasa Agama, 1.

${ }^{35}$ Jorge J. E. Gracia, A Theory Of Textuality, 107.
} 
Paradigma Sintesis Tafsir Teks Al-Qur'an Menimbang Hermeneutika Pemaknaan Teks Jorge J.E Gracia Sebagai Teori Penafsiran Tekstual al-Qur'an

pada teks yang terbentuk. ${ }^{36}$ Teks tidak akan pernah ada tanpa pemahaman sang pengarang historis terhadap makna yang ingin disampaikan melalui entitasentitas yang membentuk teks.

Sekalipun ia yang melahirkan dan membentuk entitas teks, pengarang bukanlah satu-satunya penentu dari makna teks. Ketika teks dilepas, maka audiens akan melihat pengarang adalah historis, penyusun entitas yang berada dalam kemapanan bahasa dan budaya tertentu. Pengarang adalah penyusunan tanda-tanda yang mengikuti aturan-aturan yang telah mapan dalam kehidupan masyarakat tertentu. Pengarang bertanggung jawab atas teks yang dibuat pada poin sebagai author, namun peran budaya dan lokalitas teks menjadi sorotan penting bagi para reader. ${ }^{37}$

Jika dikaitakan dalam konteks Islam, al-Qur'an adalah wahyu dari Allah, Allah di sini sebagai pengarang. Sebagai pengarang tentu saja mempunyai maksud dan tujuan tertentu ketika menurunkan al-Qur'an kepada umat manusia, tetapi memembatasi makna al-Qur'an dengan membatasi maksud dari pengarang adalah sesuatu yang tidak mungkin. Karena al-Qur'an ditulis dalam bahasa manusia (bahasa Arab) yang telah mempunyai aturan-aturan gramatikal sendiri. Demikian juga proses pewahyuan yang berangsur-angsur dan seringkali dalam rangka merespon peristiwa yang terjadi dalam konteks saat itu, hal ini membuat makna dan pemahaman tentang ayat-ayat yang tertulis juga akan dibatasi pada konteks saat itu. Dengan demikian, sang pengarang tidak mempunyai otoritas penuh terhadap makna dan pemahaman yang akan dihasilkan, tetapi pengarang tetap mempunyai pengaruh terhadapanya. ${ }^{38}$

${ }^{36}$ Jorge J. E. Gracia, $A$ Theory Of Textuality, 114-115.

${ }^{37}$ Jorge J. E. Gracia, $A$ Theory Of Textuality, 115-116. Hal demikian melahirkan apa yang dikenal sebagau reader-respone. Sahiron Syamsuddin menempatkan readerresponse sebagai aliran hermeneutika subjektifis. Teori ini yang berkembang dalam ranah literary studies ini mengenal sejumlah istilah kunci seperti reader, reading, text dan piece of writing. Reader adalah pembaca, reading adalah aktifitas membaca, dan text adalah pengalaman pembaca ketika ia melakukan pembacaan terhadap piece of writing. Oleh sebab itu, dalam reader-response, sebuah teks hanya bermakna apabila ia dibaca, apabila si pembaca berpartisipasi aktif dalam pemaknaan suatu tulisan (piece of writing). Makna yang akan dihasilkan oleh pembaca akan sesuai dengan pengalaman masing-masing pembaca, yang dipengaruhi banyak aspek seperti gender, kelas sosial, dan lingkungan sosio-kultural secara luas. Makna, oleh sebab itu, tidak berada di halaman, tinta di atas kertas, bahkan juga tidak di pikiran pembaca, akan tetapi di pikiran pembaca selama dan setelah ia melakukan aktifitas membaca. Fadhli Lukman, "Al-Qur'an sebagai Kitab : Telaah Pemikiran Daniel A. Madigan terhadap Al-Qur'an”, makalah di Pps UIN Sunan Kalijaga, 2013, hlm. 6. Tidak diterbitkan

${ }^{38}$ Nadia, "Hermeneutika Jorge J.E Gracia", Tesis UIN Sunan Kalijaga, 2013, 54. 
(2) Audiens. Jika sang pengarang tidak menentukan makna dari sebuah teks, bisa saja audiens juga tidak menentukan maknanya. ${ }^{39}$ Dalam hal ini audien mempunyai posisi yang sama dengan pengarang dalam konteks sama-sama menghadapi teks, serta sama-sama mengahadapi aturan-aturan umum dari entitas pembentuk teks. Meski di satu sisi audiens berkemungkinan besar lebih mengetahui makna teks dengan baik dari pada pengarang historis, namun di sisi lain audiens bukanlah pencipta teks dan penyusunnya. Sehingga, audiens juga menjadi faktor yang membatasi makna teks ${ }^{40}$

(3) Konteks. Berada dalam teks dan makna teks. Konteks juga menjadi faktor yang menentukan makna. Entitas teks bisa saja mempunyai makna berbeda jika berada dalam suatu konteks yang berbeda. Bagaimanapun juga jika pengarang dan audien dipisahkan dari konteks, mereka sama-sama tidak bisa menentukan makna. Jika pengarang dan audien dipisahkan dari konteks, maka kelompok entitas yang membentuk teks tidak bermakna. ${ }^{41}$

Implikasi dari terpisahnya teks dari pengarangnya dan terpisahnya dari konteks situasi sosial yang melahirkannya, maka teks menjadi tidak komunikatif lagi dengan keadaan sosial yang melingkupi pembaca. Sebab kadang sebuah teks diciptakan sebagai respon terhadap realitas sosial yang sedang dihadapi. Karenanya menjadi sangat penting mempertimbangakan konteks [sebagai batasan makna] baik konteks yang melingkupi pengarang, teks, dan pembacanya. Konsekuensi dari itu adalah menjadi sangat masuk akal jika teks-teks keagamaan yang ditulis oleh ulama yang tinggal di perkotaan berbeda kontens dan semangatnya jika dibandingkan dengan teks-teks keagamaan yang ditulis oleh ulama yang hidup di perkampungan. ${ }^{42}$

(4) Masyarakat dan Bahasa. Dua entitas yang dipertimbangkan menjadi faktor yang menentukan batasan makna teks. ${ }^{43}$ Bahasa yang digunakan di dalam teks merupakan hasil dari suatu masyarakat tertentu. Namun mereka bukanlah penguasa makna dari teks. Teks ada di dalam bahasa, di mana batas makna tekstual dapat ditemukan. Namun, bahasa itu sendiri tidak bisa dianggap pengatur batas-batas makna teks karena beberapa alasan. Pertama, karena makna teks yang menyusun sebuah bahasa juga tergantung pada konteks, sedangkan konteks tidak selalu bermakna linguistik atau tekstual. Kedua, bahasa mungkin berisi teks dan maknannya dalam jumlah yang tak terbatas,

\footnotetext{
${ }^{39}$ Jorge J. E. Gracia, A Theory Of Textuality, 116.

${ }^{40}$ Nadia, "Hermeneutika Jorge J.E Gracia, 55.

${ }^{41}$ Jorge J. E. Gracia, A Theory Of Textuality, 117.

${ }^{42}$ Komarudin Hidayat, Memahami Bahasa Agama, 133.

${ }^{43}$ Jorge J. E. Gracia, A Theory Of Textuality, 117-118.
} 
Paradigma Sintesis Tafsir Teks Al-Qur'an Menimbang Hermeneutika Pemaknaan Teks Jorge J.E Gracia Sebagai Teori Penafsiran Tekstual al-Qur'an

tetapi hal ini tidak berarti bahwa bahasa berisi teks yang aktual [yang sebenarnya] atau makna tekstual. ${ }^{44}$

Bahasa tidak hidup, bahasa hanya berfungsi selama pengguna menggunakannya, jadi pengguna bahasa bertanggungjawab untuk pengembangan teks dari bahasa. Peran pengguna bahasa sangat penting di mana pada perubaha konstan yang dilakukan oleh penguna bahasa. Dari sini kemudian bahasa sebagaimana teks tergantung kepada siapa yang mengunakan dan memahami mereka dan oleh karenanya tidak bisa secara eksklusif bertanggung jawab terhadap teks dan batas-batas makna teks. ${ }^{45}$

(5) Teks. Salah satu pandangan yang sangat lazim terkait dengan persoalan ini adalah bahwa batas makna teks secara eksklusif ditentukan oleh teks itu sendiri. Menurut Gracia teks adalah sekelompok entitas yang berupa tanda, yang dipilih/disusun dan diatur dimaksudkan oleh pengarang dalam konteks tertentu untuk menyampaikan makna tertentu kepada audien. Teks merupakan ciptaan historis dari seseorang yang biasa mengunakan bahasa yang berkembang secara historis untuk berkomunikasi dengan orang lain.

Sang pengarang memahami teks dan memperoleh pemahaman tertentu, tetapi dengan menulis teks dalam bahasa yang sudah ada, sang pengarang tidak bisa secara eksklusif bertanggungjawab bahkan terhadap makna yang dipahami terhadap teks yang ia miliki. Dalam beberapa kasus pengarang tidak peduli terhadap makna teks. Audiens sebagai bagian dari masyarakat menggunakan dan mengembangkan bahasa yang digunakan teks, juga mempunyai peran dalam memainkan meskipun tidak berperan secara eksklusif. Konteks juga merupakan hal yang penting sejauh makna teks tergantung pada situasi dan kondisi yang melingkupi teks, dan yang terakhir teks itu sendiri juga menentukan batasan atas dirinya sendiri. ${ }^{46}$ Dengan ini, maka bagi Gracia teks itu tidak sebatas tertulis dalam sebuah bentuk (form), ia begitu kompleks. Teks tidak berdiri sendiri, melainkan ia sebuah konstruksi (construction), kombinasi (combination) dan korelasi (correlation). ${ }^{47}$

\section{Teori dan Fungsi Interpretasi Teks Jorge J.E Gracia}

Sebagaimana di sebut di atas, triadik (kaitan tiga elemen) tafsir telah dibentuk oleh Garcia. Bagi gracia, antara interpretans dan interpretandum memiliki kaitan erat, karena lahirnya interpretans untuk menjelaskan

\footnotetext{
${ }^{44}$ Jorge J. E. Gracia, A Theory Of Textuality, 118-119.

45 Jorge J. E. Gracia, A Theory Of Textuality, 118-119.

${ }^{46}$ Jorge J. E. Gracia, A Theory Of Textuality, 4, 119-123.

${ }^{47}$ Jorge J. E. Gracia, A Theory Of Textuality, 7.
} 
interpretandum. $^{48}$ Dalam menjelaskan teori interpretasinya, Gracia mengemukakan terlebih dahulu apa yang diistilahkan dengan interpreter's dilemma, yakni keadaan kekhawatiran yang dialami oleh seorang penafsir dimana tambahan kata akan membuat audiens semakin faham atau tidak, atau malah tambahan kata itu mendistorsi teks. ${ }^{49}$

Untuk menjawab dilemma ini, Gracia memberikan jawaban dengan bangunan fungsi interpretasinya, yakni antara lain: historical function, meaning function, dan implicative function.

a) Historical Function. Gracia menjelaskan tujuan dari penafsir adalah untuk menciptakan pemahaman di benak audiens kontemporer, terkait tindakan mental yang memunculkan teks pertama kalinya (historical author) bukan orang yang mengkreasikan teks melainkan seperti kondisi masyarakat ketika teks itu muncul. ${ }^{50}$

Pandangan ini mengisyaratkan bahwa seorang penafsir harus mampu menyampaikan apa yang menjadi tujuan dari teks sejarah (historical teks) dengan pemahaman yang sama dengan apa yang diinginkan oleh historical author. Pemahaman yang dimiliki penafsir inilah yang kemudian dibawa pada audiens kontemporer sebagai satu pemahaman yang didasarkan pada kondisi psikologi historical audience. Pemaparan ini menyimpulkan bahwa tujuan penafsir adalah untuk menciptakan pemahaman pada sebuah teks di antara audiens kontemporer, artinya tugas dia sama seperti bagaimana historical author dan historical audience dulu menciptakan historical text. ${ }^{51}$ Dari sinilah kita dapat melihat lebih jelas mengapa interpretasi merupakan bagian integral dari pemahaman historical text untuk memahami sebuah teks. Tujuannya ialah untuk menjembatani kesenjangan kontekstual, konseptual, budaya dan sebagainya yang memisahkan teks dimana ia dibaca, didengar, atau bahkan diingat. ${ }^{52}$

Jawaban ini ditegaskan oleh Gracia agar menjadi patokan bahwa dalam menafsirkan punya takaran-takaran yang jika sudah kita penuhi, maka tidak perlu lagi ada kekhawatiran. Gracia menyebut hal ini dengan Principle of Propotional Undestanding. ${ }^{53}$

\footnotetext{
${ }^{48}$ Jorge J. E. Gracia, A Theory Of Textuality, 148.

${ }^{49}$ Jorge J. E. Gracia, $A$ Theory Of Textuality, 155.

${ }^{50}$ Jorge J. E. Gracia, $A$ Theory Of Textuality, 155.

${ }^{51}$ Jorge J. E. Gracia, $A$ Theory Of Textuality, 157.

${ }^{52}$ Jorge J. E. Gracia, $A$ Theory Of Textuality, 157.

${ }^{53}$ Jorge J. E. Gracia, A Theory Of Textuality, 156.
} 
1. Historical teks an historical context Historical Author+historical audience

2. Interpretation(interpretation,historical text+interpretative additions) in the contemporary context Contemporary audience

3. Acts of understanding of historical author and historical audience

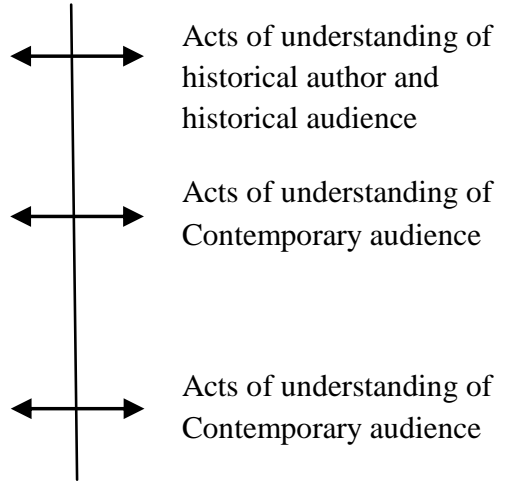

b) Meaning Function, fungsi perkembangan makna. Gracia menegaskan bahwa fungsi ini bertujuan untuk menciptakan pemahaman di benak audiens kontemporer dan mengembangkan makna dari suatu teks. Terlepas dari apakah pemaknaan tersebut sama atau tidak dengan apa yang dimaksud oleh author dan audiens historis. $^{54}$

Perkembangan makna yang dimaksud adalah suatu pemahaman tambahan dalam menafsirkan suatu teks karena kondisi yang dialami para penafsir yang berbeda- beda. Akan tetapi bukan dalam artian penafsiran tersebut hilang kendali dari makna substansi suatu teks, melainkan perkembangan makna tersebut hanyalah suatu pengembangan dari makna subtansi yang dikandung oleh teks sebagai upaya penyesuaian dengan problematika yang sedang dialami para penafsir atau dengan kata lain menghidupkan teks sesuai dengan permasalahannya. Sehingga seorang mufassir bisa saja menemukan makna lain, asalkan makna tersebut merupakan bagian dari makna keseluruhan sebuah teks (part of the overall teks). ${ }^{55}$

c) Implicative Function (fungsi penerapan). Fungsi ini bertujuan untuk memunculkan pemahaman di benak audiens, sehingga mereka memahami implikasi dari makna teks yang ditafsirkan. Pemaknaan suatu teks dapat dipahami dari tindakan yang dilakukan oleh audiens. Tindakan inilah yang nantinya dipahami sebagai fungsi penerapan. Akan tetapi antara makna dan penerapan harus tetap dibedakan walaupun makna dan penerapan terlihat sama tapi pada hakikatnya kedua kategori ini sangat berbeda. Makna hanya pada ranah konseptual sedangkan penerapan sudah lebih jauh dari konsep menjadi sebuah tindakan audiens.

\footnotetext{
${ }^{54}$ Jorge J. E. Gracia, A Theory Of Textuality, 160.

${ }^{55}$ Jorge J. E. Gracia, $A$ Theory Of Textuality, 160.
} 
Pemahaman tentang makna historis merupakan syarat yang harus dipenuhi untuk memahmi fungsi penerapan ini. Jadi seorang penafsir harus konsisten dengan makna yang ada pada teks tersebut yang kemudian menjadi makna yang dipahami oleh audiens kontemporer bukan pemahaman yang subyektif. $^{56}$ Akan tetapi hal ini bukanlah suatu yang mudah bagi seorang penafsir karena situasi yang dialami seorang penafsir dan kemunculan teks tidak sama. $^{57}$

\section{Al-Qur'an : Paradigma Tekstual dan Kenisbian Penafsiran}

Memahami al-Qur'an sebagai teks memang selalu dipandang sebagi hal yang kaku, padahal sisi tekstualitas al-Qur'an adalah hal yang rumit. Pada bagian akhir karyanya, Gracia menyimpulkan bahwa bentuk interpretasi dapat dibagi menjadi dua : (1) textual, yaitu interpretasi yang masih dalam batasan penasfsiran teks secara biasa (as act of interpretation with additional information (interpretans) dengan mempertimbangkan aspek kesejarahannya. (2) non-textual, yakni penafsiran yang melampaui teks, sehingga tidak lagi berpangku hanya pada makna di balik dan implikasinya, namun lebih jauh dari itu (produce beyond wording text meaning. Here, the goal of interpretation is to produce understanding not only based on the text with its meaning and implication of text it self but its relation with other texts and aspect beyond.). ${ }^{58}$

Baik tekstual maupun non-tekstual bagi Gracia bisa saja masuk dalam subyektif dan obyektif penafsiran. Ukuran sederhananya bahwa penafsiran obyektif itu memiliki usaha dan perhatian yang besar dalam menggali kesejarahan teks (high attention to interpretandum and historical aspect), adapun subyektif itu sebaliknya "low attention interpretandum and historical aspect". ${ }^{.59}$ Bahkan dengan posisi tafsir textual pun, ia tidak memiliki kebenaran tunggal dan anti-kesempurnaan.

Dua fungsi penafsiran terakhir menjadi basis penekanan Gracia, bahwa tafsir pasti berbeda antar orang, berbeda karena banyak aspek dan faktor pendorong lainnya. ${ }^{60}$ Bisa saja sebuah tafsir tekstual mencapai puncak paling benar, dengan kesamaan frame work dan kultur. Namun, hal ini agak mustahil terwujud, dengan kenyataan faktual yang ada dan melingkupi mufassir. Bahkan tiga fungsi di atas bagi Gracia sebagai tolak ukur (truth value) dalam

\footnotetext{
${ }^{56}$ Jorge J. E. Gracia, A Theory Of Textuality, 161.

${ }^{57}$ Jorge J. E. Gracia, $A$ Theory Of Textuality, 161.

${ }^{58}$ Jorge J. E. Gracia, A Theory Of Textuality, 178-179.

${ }^{59}$ Jorge J. E. Gracia, $A$ Theory Of Textuality, 178-179.

${ }^{60}$ Jorge J. E. Gracia, A Theory Of Textuality, 163.
} 
Paradigma Sintesis Tafsir Teks Al-Qur'an Menimbang Hermeneutika Pemaknaan Teks Jorge J.E Gracia Sebagai Teori Penafsiran Tekstual al-Qur'an

menentukan sebuah tafsir efektif atau tidak efektif. ${ }^{61}$ Gracia lebih senang menyebutnya dengan hal itu, dibandingkan dengan istilah tafsir benar dan tidak benar, karena masing-masing fungsi memiliki nilai kebenaran yang berbeda. ${ }^{62}$

Menurut Gracia, terdapat batas-batas makna dari teks yang akan dipahami. Tetapi batasan makna itu sangat tergantung pada beberapa faktor. Oleh karenanya kita tidak diharuskan untuk mengerti makna teks itu secara sempit. Ia menekankan makna teks itu terbatas, dan batasan-batasan ini harus dipahami dalam konteks inti dari makna dan bukan dari sesuatu yang mungkin dipahami ketika seseorang mengatakan bahwa ia memahami suatu teks. Dalam pandangan Gracia beberapa faktor yang mungkin dapat memengaruhi dan menetapkan batas-batas makna di antaranya adalah pengarang, audien, konteks, masyarakat, bahasa dan teks itu sendiri kemudian fungsi budaya (cultural fuctions). ${ }^{63}$

Goal sebuah interpretasi bagi Gadamer dan Gracia justru tidak hanya reproduktif makna belaka, melainkan juga produktif dalam melahirkan makna baru. Reproduksi makna menjadi konsekuensi logis, karena setiap mufassir tidak dapat melepaskan diri dari situasi historis di mana kita berada. Karena, upaya untuk menjembatani jurang antara waktu penafsir dengan waktu pengarang adalah mustahil atau ilusi. Bagi Gadamer, "prasangka" dan "tradisi" penafsir harus diafirmasi sebagai horison historis yang memungkinkan pemahaman terhadap teks. ${ }^{64}$ Begitu pula bagi Gracia, bahwa entitas historis teks dan pengarang harus menjadi acuan utama dalam mengkaji teks, untuk selanjutnya ditafsirkan dengan makna yang lebih relevan. ${ }^{65}$

Peran sang penafsir yang selalu dilingkupi oleh kultur yang berbeda satu sama lain, dan selalu berkembang dari zaman ke zaman, secara pasti akan melahirkan pola pemikiran yang berbeda, dan konsekuensinya interpretasi terhadap teks suci itu juga berbeda. Dari sinilah corak-corak tafsir muncul yang berjalan seiring dengan "kecenderungan" sang penafsir. Dari perspektif ini, maka sang tokoh menjadi parameter atas tafsirannya. Selain tokoh, parameter persfektif tafsir juga bisa dilihat dari seiapa pembacanya (reader) dan teksnya sendiri $($ text $){ }^{66}$

52.

${ }^{61}$ Nadia, "Hermeneutika Joerge J.E Gracia ", 67.

${ }^{62}$ Jorge J. E. Gracia, A Theory Of Textuality, 173.

${ }^{63}$ Jorge J. E. Gracia, $A$ Theory Of Textuality, 114.

${ }^{64}$ Syahiron Syamsuddin, Hermeneutika Dan Pengembangan Ulumul Qur'an, 44-

${ }^{65}$ Syahiron Syamsuddin, Hermeneutika Dan Pengembangan Ulumul Qur'an, 55.

${ }^{66}$ Ahmad Jainuri, "Teori Interpretasi Dalam Perspektif Filsafat Hermeneutika", dalam jurnal Mukaddimah, No. V, 1999. hlm. 124-129. 
Ahmad Jainuri memberikan tiga paradigma besar dalam tafsir. Pertama, interpretasi yang terfokus pada penulis (an author centered interpretation) bahwa interpretasi mestinya menjangkaui makna di luar teks, dengan menghubukannya dengan konteks geografis, historis, budaya, sosial politik dan bahasa. Kedua, interpretasi yang terfokus pada pembaca (an reader centered interpretation), relasi yang dibangun dalam bagian ini adalah relasi dunia yang ada didepan tek (teks dan masyarakat pembacanya). Ketiga, interpretasi yang terfokus pada teks (text a centered interpretation), yakni mengungkapkan dunia yang ada dalam teks itu, dua hal yang menjadi tekanan yaitu, narasi teks dan subyek teks tersebut. ${ }^{67}$

Ketika menemukan kesulitan dalam memahami pesan dalam sebuah kitab suci itu, hermeneutika menjadi alternasi perangkat bedah, di samping juga teori interpretasi lainnya. Walaupun masih menyisakan dua poros yang bertolak belakang dalam menyikapi, tidak dapat dibantah bahwa memasuki abad ke-20, kajian hermeneutika semakin berkembang. Sebagai sebuah metode interpretasi, hermeneutika sangat besar pengaruhnya bagi keilmuan. Bagi hermeneutika pemaknaan teks, sebuah teks hanya bermakna apabila ia dibaca, apabila sipembaca berpartisipasi aktif dalam pemaknaan suatu tulisan. Makna yang akan dihasilkan oleh pembaca akan sesuai dengan pengalaman masing-masing pembaca yang dipengaruhi banyak aspek seperti; gender, kelas sosial, dan lingkungan sosio-kultural secara luas. Makna, oleh sebab itu, tidak berada di halaman, tinta di atas kertas, bahkan juga tidak di pikiran pembaca, akan tetapi di pikiran pembaca selama dan setelah ia melakukan aktifitas membaca. ${ }^{68}$

\section{Penutup}

Dari kajian dan uraian mengenai hermeneutika pemaknaan teks dan paradigma tafsir tekstual di atas, maka kesimpulan dalam artikel ini bisa ditarik pada tiga garis besar.

Pertama, konsep teks al-Qur'an atau al-NașS merupakan konsep yang tampak sampai sekarang, ketika menjadi mushaf pada masa Utsman al-Qur'an menjadi kitab teks tertulis. Dengan demikian, tekstualitas al-Qur'an dalam menafsirkan adalah adalah kesadaran utama yang mesti dibangun, sebab alQur'an adalah sesuatu terbaca/tersentuh (al-Maktūb). Ke-maktūb-an al-Qur'an terlihat karena al-Qur'an memiliki entitas ḥurf, al-qur'ān, al-kitāb āyāt, kalimāt dan al-risālah yang tersusun rapi, khas dan membedakan dengan teks semasanya maupun teks sebelumnya. Sebagai al-Nașs, al-Qur'an memiliki mekanisme teks

\footnotetext{
${ }^{67}$ Ahmad Jainuri, “Teori Interpretasi . . . “, h. 124-129.

${ }^{68}$ Sahiron Syamsuddin, Hermeneutika dan Pengembangan, h. 26.
} 
Paradigma Sintesis Tafsir Teks Al-Qur'an Menimbang Hermeneutika Pemaknaan Teks Jorge J.E Gracia Sebagai Teori Penafsiran Tekstual al-Qur'an

yang pendekatan ketekstualitasan adalah pintu utama dalam membuka maknanya sebagai teks. Dengan demikian, maka teks dan makna adalah entitas yang terkait namun keduanya dari entitas yang berbeda.

Kedua, nalar hermeneutis pemaknaan teks ala Gracia diarahkan pada mengatasi ketidakpahaman (misunderstanding) dan bukan pemahaman (undestading) dari sebuah teks dengan metode the development of textual interpretation, guna menjembatani kesejarahan teks dengan keadaan audiens. Teks bagi Gracia adalah entitas yang hidup menyangkut banyak segi yang perlu dipahami dengan jalur undestanding (al-bayān), explain (al-fahm) dan implicative (istikhrāj). Sebagai teks, al-Qur'an adalah entitas yang di dalamnya menyangkut banyak poin yang mesti dianalisis, karena sebagai teks al-Qur'an memiliki konteks, audiens, masyarakat. Elemen teks tersebut adalah entitas yang terpisah yang akan digerakkan semua dalam memahami teks, teks yang harus dipahami dengan audiens sebagai aktor yang melakukan aktifitas dalam memahami makna yang terkandung dalam teks.

Ketiga, paradigma tafsir tekstual merupakan cara pandang terhadap terhadap al-Qur'an dan penafsirannya, dengan konsep "an-nașş" sebagai titik berangkat, bekerja dengan menekankan pada adanya pemahaman yang baik antara teks, audiens dan konteks. Konteks dalam maksud ini adalah konteks teks, bukan konteks yang difahami dalam tafsir kontesktual, teks al-Qur'an bukan sebatas tertulis dalam sebuah bentuk (form), ia begitu kompleks, ia sebuah konstruksi (construction), kombinasi (combination) dan korelasi (correlation). Dengan demikian, paradigma tafsir tekstual adalah hal yang luas untuk difahami dari hanya sekedar tafsir yang kaku, klasik dan lain sebagainya.

\section{Daftar Pustaka}

al-‘Akk, Khalid Abd al-Rahman. Uṣul al-Tafsīr wa Qawā'iduhu. Beirut: Dār alNafa' is, 1986.

al-Sabt, Khālid ibn 'Uthmān. Qawā'id al-Tafsìr: Jam'an wa Dirāsatan. Kairo: Dār Ibn 'Affān, $1421 \mathrm{H}$.

al-Żahabī, Muhammad Husayn. al-Tafsìr wa al-Mufassirūn. Kairo: Maktabah Wahbah, t.t.

al-Zarqānì, Muhammad 'Abdul 'Aẓim. Manāhil al-'Irfān fí 'Ulūm al-Qur'ān. Beirūt: Dār al-Kutūb al-‘Arābi, 1995.

Faiz, Fachrudin. Hermeneutika al-Qur'an: Tema-tema Kontroversial. Yogyakarta:eLSAQ Press, 2005. 
Gracia, Jorge J. E. A Theory Of Textuality: The Logic And Epistemology . Albany: State University Of New York Press. 1995.

Hidayat, Komarudin. Memahami Bahasa Agama: Sebuah Pendekatan Hermeneutik. Jakarta: Paramadina. 1996.

Jainuri, Ahmad. "Teori Interpretasi Dalam Persfektif Filsafat Hermeneutika", dalam jurnal Mukaddimah, No. V, 1999.

Khamdan (Dkk.), Studi Al-Qur'an: Teori dan Metodologi,. Yogyakarta: Idea Press. 2011.

Setiawan, M. Nur Kholis. Al-Qur'an Kitab Sastra Terbesar. Yogyakarta: Elsaq Press, 2006.

Syahrur, Muhammad. "The Divine Text and Pluralsm in Moslem Societies", terj. Muhammad Zaki Hussein dalam Sahiron Syamsuddin, dkk. Hermeneutika al-Qur'an Madzhab Yogya (Yogyakarta, Islamika dan Forstudia, 2003.

Syamsuddin, Sahiron. Hermeneutika dan Pengembangan Ulumul Qur'an,. Yogyakarta: Pesantren Nawesea Press. 2009.

www.acsu.buffalo.edu/gracia/cv.html

Zayd, Naṣr Hāmid Abū. Mafhūm al-Naș̣: Dirāsah fī 'Ulūm al-Qur'ān. Beirut: Markaz aś-ŚSaquî al -'Arābi, 2000.

------. Al-Quran, Hermeneutik dan Kekuasaan : Kontroversi dan Penggugat Hermeneutika al-Qur'an, Terj. Dede Iswadi (Dkk.). Bandung: RQiS, 2003.

------. Mafhūm al-NașS, al-Sulțān, al-Haqiquah: al-Fikr al-Dīni bayn Irādat alMa'rifat wa Irādat al-Hayminat. Beirūt: Markaz aś-ŚSaqafĩ al -'Arābi, 1995.

------. Naqd Khițāb ad-Dïni. Kairo: Sina li an-Nașr, tt. 